\title{
MENAKAR PELUANG PELINDUNGAN INDIKASI GEOGRAFIS PADA BIDANG JASA DALAM KERANGKA HUKUM INDONESIA: SEBUAH DIAGNOSA AWAL
}

\author{
Muh. Ali Masnun \\ Fakultas Ilmu Sosial dan Hukum, Universitas Negeri Surabaya \\ alimasnun@unesa.ac.id
}

Submitted: 2020-12-16 | Reviewed: 2021-08-26 | Accepted: 2021-11-08

\footnotetext{
How to cite: Muh. Ali Masnun.

"Menakar Peluang Perlindungan Indikasi Geografis Pada Bidang Jasa Dalam Kerangka Hukum Indonesia: Sebuah Diagnosa Awal". Dialogia Iuridica: Jurnal Hukum Bisnis dan Investasi, Vol. 13, No. 1, (2021), 047060.
}

DOI:

https://doi.org/10.28932/di.v13i1.3198

\begin{abstract}
The protection of geographical indications in Indonesia is still limited to the goods sector, but not yet for the service sector. The purpose of this study is to analyze the opportunities for the protection of geographical indications in the service sector within the legal framework in Indonesia. This research is a doctrinal research using a conceptual and statute approachs. The results of the study can be concluded that the opportunity for protection of geographical indications in the service sector is very good with an argument consisting of 4 aspects, including the provisions of the TRIPS agreement which are open, the potential for uniqueness of the region. based services, protection through the relative geographical indications still has weaknesses, and protection through communal intellectual property (traditional knowledge) is also relatively weak. The opportunities for the protection of geographical indications are also very relevant to several legal protection theories, including: predictive and anticipatory legal protection theory, integrative and coordinative theory, and social ownership theory.
\end{abstract}


Keywords: Geographical Indication, Indonesia, Services

\section{PENDAHULUAN}

Negara kepulauan (archipelagic state) selalu melekat kepada bangsa Indonesia. Bahwa konsepsi negara kepulauan berasal dari pengertian Nusantara, yang berasal dari kata "nusa" yang berarti kumpulan (gugusan) pulau, dan "antara" diartikan suatu tempat yang terletak benua dan di antara diartikan suatu tempat yang terletak atau diapit oleh tempat yang lain. ${ }^{1}$ Berdasarkan hal tersebut maka dapat dimaknai sebagai Negara yang terdiri atas pulau-pulau diantara beberapa benua dan samudra. Tercatat ada sekian ribu pulau yang tersebar mulai sabang hingga merauke dan miangas hinga rote dengan berbagai potensi sumber daya alam yang sangat besar ${ }^{2}$ atau pun sumber daya manusia melalui budaya yang dihasilkan hingga diakui oleh bangsa lain. ${ }^{3}$ Kehadiran berbagai Negara asing menjadi salah satu bukti bagaimana melihat Indonesia (nusantara) pada saat itu mempunyai kekayaan alam yang menjadi komoditi seksi dan terkenal hingga manca Negara. Pada sisi lain sumber daya manusia juga memiliki karya fenomenal yang menunjukkan majunya sebuah peradaban, sebagai contoh bangunan candi Borobudur yang hingga diakui United Nations Educational, Scientific and Cultural Organization (UNESCO) sebagai warisan dunia.

Memperbincangkan kekayaan sumber daya alam maupun sumber daya manusia Indonesia tentu tidak hanya aspek ekonomi saja melainkan juga ada aspek hukum. Sebagai contoh adalah Kopi Kintamani yang begitu terkenal hingga manca Negara yang ditanam di daerah Kintamani Bali. Kopi Kintamani memiliki cita rasa yang khas dan tidak bisa dihasilkan atau diproduksi di daerah lain (karena faktor alam di wilayah Kintamani). Kopi Kintamani memiliki aspek ekonomi karena menghasilkan specialty kopi arabika yang berkualitas ekspor ${ }^{4}$ dan dapat memberikan kemanfaatan kesejahteraan masyarakat setempat. Sementara dari aspek hukum bagaimana memberikan pelindungan dan kemudahan kepada masyarakat lokal dalam mengembangkan ekonomi lokal. ${ }^{5}$ Kopi Kintamani Bali menjadi pelopor produk perkebunan yang pertama kali memperoleh sertifikasi Indikasi Geografis (IG) dengan

\footnotetext{
${ }^{1}$ Amiek Soemarmi, et.al, "Konsep Negara Kepulauan dalam Upaya Perlindungan Wilayah Pengelolaan Perikanan Indonesia”, Masalah-Masalah Hukum, Volume 48 No. 3, 2019, hlm 245.

${ }^{2}$ Ayub Torri Satriyo Kusumo, "Optimalisasi Pengelolaan dan Pemberdayaan Pulau-Pulau Terluar dalam Rangka Mempertahankan Keutuhan Negara Kesatuan Republik Indonesia”, Jurnal Dinamika Hukum, Volume 10 No 3, 2010, hlm 328.

${ }^{3}$ Isni Wahyuningsih, "Meninjau Kembali Tujuan Pendirian dan Fungsi Museum-museum di Kompleks Taman Wisata Candi Borobudur", Jurnal Konservasi Cagar Budaya Borobudur, Volume 10 No. 2, 2016, hlm 45.

${ }^{4} \mathrm{Ni}$ Wayan Rainy Priadarsini Sukiada dan Anak Agung Ayu Intan Parameswari, "Nation Branding Kopi Arabika Kintamani”, SOCA: Jurnal Sosial Ekonomi Pertanian, Volume 14 No. 1, 2020, hlm 180.

5 Sudjana, "Implikasi Perlindungan Indikasi Geografis Berdasarkan Undang-Undang Nomor 20 Tahun 2016 Terhadap Pengembangan Ekonomi Lokal”, Jurnal Veritas Et Justitia, Volume 4 No. 1, 2018, hlm 30.
} 
ciri khas dan kualitas yang berbeda dengan jenis kopi lainnya. ${ }^{6}$ Berdasarkan beberapa contoh tersebut menunjukkan bagaimana kekayaan yang dimiliki oleh bangsa Indonesia sangat patut untuk dibanggakan.

Aspek hukum mengenai sebuah kekayaan alam sebagaimana tersebut menurut Undang-Undang Nomor 20 Tahun 2016 tentang Merek dan Indikasi Geografis (UU Merek 2016) dapat dilindungi melalui indikasi geografis (IG) atau pun indikasi asal (IA). Menurut Cita Yustisia bahwa IG adalah bagian dari hak merek yang dapat dimiliki oleh sebuah komunitas atau sekelompok masyarakat di daerah tertentu yang telah terbukti dapat menghasilkan dan memelihara produk khas daerah tersebut. ${ }^{7}$ Definisi juga diungkapkan Miranda Risang Ayu yang memaknai IG sebagai nama dagang yang dikaitkan, dipakai, atau dilekatkan pada kemasan suatu produk dan berfungsi menunjukkan asal tempat produk tersebut. ${ }^{8}$ Definisi resmi berdasarkan UU Merek 2016 bahwa IG adalah tanda yang menunjukkan asal suatu barang karena faktor alam, manusia atau kombinasi keduanya yang memiliki kualitas, reputasi dan karakteristik tertentu. Dengan demikian IG dapat dimaknai sebagai tanda yang melekat pada suatu barang tertentu, yang mana barang tersebut memiliki kekhasan yang dikarenakan karena faktor tertentu (alam, manusia, atau kombinasi). Sementara IA menurut Isnani adalah tanda yang semata-mata menunjukkan asal suatu barang atau jasa. ${ }^{9}$ Berdasarkan UU Merek 2016 disebutkan indikasi asal adalah tanda yang menunjukkan asal suatu barang dan/atau jasa bukan karena faktor alam. Mengacu beberapa definisi tersebut, pada dasarnya IA hampir memiliki persamaan dengan IG, hanya saja bahwa IA melekat pada barang ataupun jasa dan bukan karena faktor tertentu. Perbandingan terkait IG dan IA dapat dilihat pada tabel 1 .

Tabel 1

Perbandingan Indikasi Geografis dan Indikasi Asal

\begin{tabular}{|c|c|c|}
\hline Variabel & Indikasi Geografis & Indikasi Asal \\
\hline \multirow[t]{4}{*}{ Dasar hukum } & Pasal 53-62 UU Merek dan IG & Pasal $63-65$ UU \\
\hline & Permenkumham No 12 Tahun 2019 & Merek dan IG \\
\hline & Tentang IG & Belum diatur \\
\hline & & dalam Permen \\
\hline \multirow[t]{2}{*}{ Ruang lingkup } & Barang dan/atau produk: & Barang \\
\hline & $\begin{array}{l}\text { Sumber daya alam; barang kerajinan } \\
\text { tangan; atau hasil industri }\end{array}$ & Jasa \\
\hline Sistem & Konstitutif (mewajibkan pendaftaran) & Deklaratif (tidak \\
\hline Pelindungan & & perlu pendaftaran) \\
\hline
\end{tabular}

\footnotetext{
${ }^{6}$ Fokky Fuad dan Avvan Andi Latjeme, "Perlindungan Indikasi Geografis Aset Nasional pada Kasus Kopi Toraja", Jurnal Magister Ilmu Hukum (Hukum dan Kesejahteraan), Vol. 2 No. 2, 2017 hlm.10.

7 Cita Yustisia Serfiyani, et.al, Buku Pintar HAKI dan Warisan Budaya, Yogyakarta: Gadjah Mada University Press, 2017, hlm 420.

${ }^{8}$ Miranda Risang Ayu, Memperbincangkan Hak Kekayaan Intelektual Indikasi Geografis, Bandung: PT Alumni, 2006, hlm.1.

${ }^{9}$ Isnani, "Identifikasi dan Pemanfaatan Indikasi Geografis dan Indikasi Asal Melalui Program Pembinaan Pada Masyarakat”, Jurnal Pengabdian Hukum Indonesia, Volume 2 No. 1, 2019, hlm 42.
} 


\section{Jangka Waktu Unlimited, selama terjaganya reputasi, Belum diatur kualitas, dan karakteristik}

Berdasarkan tabel 1 maka tampak perbedaan yang cukup signifikan antara IG dan IA. Pada aspek dasar hukum IG relatif lebih lengkap dibandingkan IA yang terkesan "dianaktirikan". Pada aspek ruang lingkup, bahwa IG lebih sempit karena terbatas hanya pada bidang barang saja, sementara IA lebih luas karena mencakup barang dan/atau jasa. Perlindungan indikasi geografis meliputi barang barang yang dihasilkan oleh alam, barang hasil pertanian, hasil kerajinan tangan; atau hasil industri lainnya. ${ }^{10}$ Mengenai sistem pelindungan, bahwa IG sifatnya konstitutif yang artinya bahwa ada kewajiban pendaftaran ke Direktorat Jenderal Kekayaan Intelektual (DJKI) untuk dapat dilindungi, sementara IA sifatnya deklaratif (tidak perlu melakukan pendaftaran untuk memperoleh pelindungan). Dalam hal jangka waktu perlindungan, IG secara jelas melindungi sepanjang reputasi, kualitas, dan karakteristik masih tetap terjaga sementara IA belum diatur dalam regulasinya.

Ruang lingkup pelindungan IG menarik bila diperhatikan bahwa ada beberapa Negara yang juga melindungi IG tidak hanya pada barang saja, melainkan juga di bidang jasa sebagai contoh Kanada, Meksiko, Jepang, dan Swiss. Bidang jasa tersebut meliputi health services, spas and traditional healing methods. Bila memperhatikan bidang jasa yang dilindungi IG di beberapa Negara lain, Indonesia dengan kekayaan budayanya pada dasarnya juga memiliki berbagai metode pengobatan, kesehatan ataupun jasa lain yang mana hal tersebut juga sangat berpotensi untuk dilindungi sehingga dapat memberikan manfaat bagi masyarakat. Sebagai contoh pengobatan "suwuk" di jawa, Batatamba yang merupakan teknik pengobatan yang sangat terkenal di Masyarakat Banjar, teknik untuk memaksimalkan kekuatan energi tubuh melalui Usada Bayu di Bali.

Berdasarkan hal tersebut menarik untuk dielaborasi bagaimana peluang pelindungan IG pada bidang jasa dalam kerangka hukum di Indonesia. Tujuan dari riset ini untuk menganalisis bagaimana pelindungan IG tidak hanya diberikan pada bidang barang saja, melainkan juga bidang jasa. Untuk mencapai tujuan tersebut, artikel ini disusun dengan diawali pendahuluan akan dilanjutkan dengan bagian berikutnya mengenai metode penelitian yang menguraikan penelitian yang digunakan, pendekatan yang digunakan untuk mengelaborasi permasalahan, serta metode analisis yang digunakan. Bagian berikutnya merupakan bagian inti yang merupakan hasil dan pembahasan yang akan menguraikan beberapa bagian antara lain dinamika pengaturan IG di Indonesia, pelindungan IG bidang jasa dikaitkan dengan pelindungan indikasi asal dan pengetahuan tradisional di Indonesia. Bagian terakhir menguraikan simpulan dan rekomendasi atas hasil riset ini.

\footnotetext{
10 Yusran Isnaini, Buku Pintar HAKI Tanya Jawab Seputar Hak Kekayaan Intelektual, Bogor: Ghalia, 2010, hlm 133.
} 
Penelitian sejenis telah dilaksanakan oleh beberapa pihak antara lain, Nizar Apriansyah pada tahun 2018 yang memfokuskan penelitian bagaimana pelindungan indikasi geografis di Indonesia dapat mendorong perekonomian di daerah. ${ }^{11}$ Riset lain juga telah dilakukan pada tahun 2016 oleh Trias Palupi Kunianingrum ${ }^{12}$ yang fokus risetnya mengenai urgensi atau dasar pelindungan hak ekonomi atas indikasi geografis dan bentuk pelindungan hak ekonomi atas indikasi geografis di Indonesia. Riset lain telah dilakukan Muhammad Ali Ridla ${ }^{13}$ yang kajiannya lebih pada aspek bagaimana pelindungan IG yang belum terdaftar dengan menggunakan pendekatan first to use system pada tahun 2019. Secara umum belum ada yang melakukan riset terkait peluang pelindungan IG pada bidang jasa dalam kerangka hukum di Indonesia.

Riset dalam artikel ini termasuk dalam kategori salah riset hukum doktrinal dengan menggunakan pendekatan konseptual, pendekatan sejarah dan pendekatan perundang-undangan. Pendekatan konseptual dilakukan dengan menelaah konsep HKI dan IG dengan memperhatikan berbagai regulasi baik di tingkat nasional maupun internasional. Pendekatan sejarah digunakan untuk menguraikan dinamika perkembangan pengaturan IG dari waktu ke waktu. Pendekatan perundang-undangan dengan menekankan bagaimana pengaturan IG pada berbagai peraturan. Adapun pengumpulan data sekunder dilakukan dengan studi kepustakaan melalui penelusuran bahan hukum primer maupun sekunder. Bahan hukum yang diperoleh dianalisis secara preskriptif dengan mengacu pada teori, konsep, sehingga dapat diperoleh sebuah simpulan.

\section{PEMBAHASAN}

Indonesia sebagai negara kepulauan menyimpan begitu banyak kekayaan alam dengan keunikannya masing-masing yang bercirikan daerah asalnya. Atas dasar hal tersebut maka tidak heran apabila terdapat begitu banyak produk-produk yang memiliki IG maupun potensi IG dari setiap daerahnya. ${ }^{14}$ IG merupakan tanda atau ekspresi yang mencerminkan daerah asal suatu barang yang karena faktor lingkungan geografis meliputi faktor alam, faktor manusia atau kombinasi dari kedua faktor tersebut yang selanjutnya memberikan kekhasan karakteristik, ciri serta kualitas tertentu pada suatu produk tertentu. ${ }^{15}$

Pelindungan IG sangat, hal tersebut sangat beralasan mengingat IG merupakan hak milik yang memiliki nilai ekonomi (economic value), sehingga perlu mendapat perlindungan hukum. Banyaknya produk berbagai daerah yang ada di Indonesia yang

\footnotetext{
11 Nizar Apriansyah, "Protection of Geographical Indications within the Scope of Improvement of Regional Economy”, Jurnal Penelitian Hukum De Jure, Volume 18 No. 4, 2018, hlm 525.

12 Trias Palupi Kurnianingrum, "Pelindungan Hak Ekonomi Atas Indikasi Geografis", Jurnal Negara Hukum, Volume 7 No. 1, 2016, hlm 19.

13 Muhammad Ali Ridla, "Perlindungan Indikasi Geografis Terhadap Kopi Yang Belum Terdaftar Menurut First-To-Use-System", Jurnal Hukum Bisnis Bonum Commune, Volume 2 No 2, 2019, hlm 116.

${ }^{14}$ Lily Karuna Dewi dan Putu Tuni Cakabawa Landra, "Perlindungan Produk-Produk Berpotensi Hak Kekayaan Intelektual Melalui Indikasi Geografis”, Jurnal Kertha Semaya, Vol 7 No 3, 2019, hlm. 2.

15 I Ketut Haris Wiranata dan Anak Agung Sri Indrawati, "Pendaftaran Kembali Hak Merek Dagang Indikasi Geografis”, Jurnal Kertha Semaya, Vol. 2 No. 5, 2014, hlm 2.
} 
telah dikenal dan mendapatkan tempat di pasar internasional sehingga memiliki nilai ekonomi (economic value) yang tinggi, hal ini perlu diikuti dengan perlindungan hukum untuk bisa melindungi komoditas tersebut dari praktek persaingan curang dalam perdagangan. ${ }^{16}$ Dalam pelindungan terdapat hak-hak yang memungkinkan untuk mencegah penggunaan oleh pihak ketiga yang produknya ${ }^{17}$ memiliki kesamaan dengan pemilik IG tanpa ada izin. Kopi Gayo dan Kopi Toraja menjadi salah satu contoh bagaimana telah didaftarkan dahulu oleh pihak lain (negara lain), yang mana pihak lain tersebut bukanlah penghasil kedua kopi tersebut.

Memperbincangkan pelindungan IG sebagaimana tersebut selalu menjadi kajian yang menarik. Hal tersebut sangat beralasan, karena IG memiliki kekhasan apabila dibandingkan dengan Merek. IG memiliki dua fungsi, di satu sisi memberikan pelindungan bagi konsumen untuk secara langsung melawan tindakan penggunaan indikasi yang salah atau menyesatkan dan sisi lain memberikan perlindungan goodwill bagi mereka yang berhak atas IG tersebut. ${ }^{18}$ Kekhasan IG tersebut selaras dengan yang diungkapkan Wahyu Sasongko dalam artikelnya bahwa kekhasan IG dibanding HKI lain setidaknya empat unsur pokok antara lain yaitu: pertama, bahwa unsur nama geografis untuk mengindentifikasi, tidak bersifat mutlak tetapi relatif karena dapat menggunakan nama nongeografis. Kedua, unsur wilayah dalam Negara sebagai tempat produksi tidak identik dengan wilayah administratif, namun disesuaikan dengan kondisi faktual. Ketiga, unsur kepemilikan dalam IG yang bukan merupakan hak individual melainkan hak komunal, maka IG merupakan hak untuk menggunakan (right to use). Keempat, unsur kualitas, reputasi, atau karakteristik lain yang bersifat alternatif, maka suaut barang sudah cukup memenuhi salah satu unsur tersebut. ${ }^{19}$

Sebagai catatan, bahwa sampai dengan saat ini sebanyak 92 IG telah terdaftar di $\mathrm{DJKI}^{20}$, sementara potensi pelindungan IG yang telah masuk daftar DJKI terdapat $21 .^{21}$ Angka tersebut relatif masih sedikit apabila dibandingkan dengan kekayaan yang dimiliki oleh Indonesia dan juga IG yang dilindungi di Negara lain. Berdasarkan Database Statistik WIPO tahun 2018 bahwa China sebagai Negara yang memiliki jumal IG terbanyak dengan jumlah 8.507, yang disusul EU dengan jumlah 4.932, Republik Moldova diurutan ketiga dengan jumlah 4.615. India yang dapat dikategorikan sebagai Negara berkembang di Asia Selatan memiliki jumlah 305 IG terdaftar (lihat Grafik 1). Apabila melihat perbandingan tersebut, maka Indonesia yang dikenal sebagai Negara

\footnotetext{
${ }^{16}$ Saky Septiono, Perlindungan Indikasi Geografis dan Potensi Indikasi Geografis Indonesia, Jakarta: DJKI, Kementerian Hukum dan HAM RI, 2009, hlm 1.

${ }^{17}$ Dara Quthni Effida, "Tinjauan Yuridis Indikasi Geografis sebagai Hak Kekayaan Intelektual NonIndividual (Komunal)", Jurnal Ius Civile, Vol 3 No 2, 2019, hlm. 59.

18 Rahmi Jened, Hak Kekayaan Intelektual Penyalahgunaan Hak Eksklusif, Surabaya: Airlangga University Press, 2010, hlm. 193.

19 Wahyu Sasongko, "Indikasi Geografis Rezim HKI yang Bersifat Sui Generis", Jurnal Media Hukum, Vol 19 No 1, 2012, hlm 99.

20 "E Indikasi Geografis", http://ig.dgip.go.id/, diakses pada pada tanggal 25 November pukul 20.00 WIB.

21 "Pusat Data Nasional Kekayaan Intelektual Komunal Indonesia", http://kikomunalindonesia.dgip.go.id/index.php/, iakses pada pada tanggal 30 November pukul 19.30 WIB.
} 
Dialogia luridica: Jurnal Hukum Bisnis dan Investasi

Volume 13 Nomor 1, November 2021

kepulauan dengan kesuburan tanahnya bukan tidak mungkin memiliki jumlah IG lebih daripada itu.

Grafik 1

Database Jumlah Indikasi Geografis

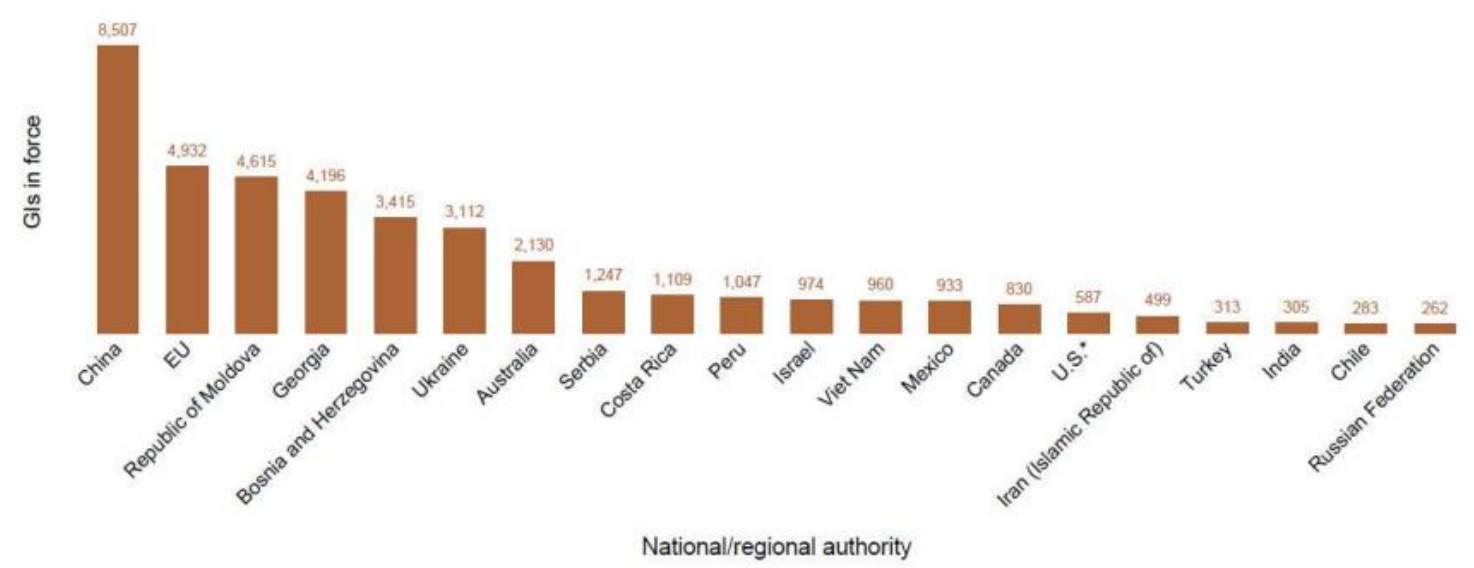

Sumber: Statistik Database WIPO

Jumlah IG yang dimiliki di Indonesia tentu juga salah satunya dipengaruhi bagaimana regulasi atau pengaturan terkait pelindungan IG apakah sulit atau cukup mudah untuk melindunginya. Bahwa pengaturan IG di Indonesia mengalami dinamika dan terus mengalami perubahan sebagaimana tersaji pada tabel 2 di bawah ini.

Tabel 2

Perbandingan Pengaturan Indikasi Geografis di Indonesia

\begin{tabular}{lllll}
\hline Variabel & \multicolumn{2}{c}{ UU Merek 1997 } & UU Merek 2001 & \multicolumn{2}{c}{ UU Merek 2016 } \\
\hline Pengaturan & Pasal 79A, 79B, 79C, Pasal 56 & hingga & Mulai Pasal 53 hingga \\
& 79D, dan 79E & Pasal 58 & Pasal 71 & \\
\hline Definisi & Belum mengatur secara & Idem & suatu tanda yang \\
& pasti definisi dalam & menunjukkan daerah \\
& ketentuan umumnya, & asal suatu barang \\
& namun demikian & dan/atau produk yang \\
& dikatakan bahwa suatu & karena & faktor \\
& IG dapat dilindungi & lingkungan geografis \\
& Sebagai suatu tanda & termasuk faktor alam, \\
& yang menunjukkan & faktor manusia atau \\
& daerah asal suatu & kombinasi dari kedua \\
& barang, yang karena & faktor & tersebut \\
& faktor lingkungan & memberikan reputasi, \\
& geografis termasuk & kualitas, & dan \\
& faktor alam, faktor & karakteristik tertentu \\
& manusia atau kombinasi & pada barang dan/atau \\
dari kedua faktor & produk & yang \\
tersebut, memberikan & dihasilkan. & \\
\hline
\end{tabular}




\begin{tabular}{|c|c|c|c|}
\hline & $\begin{array}{l}\text { ciri dan kualitas tertentu } \\
\text { pada barang yang } \\
\text { dihasilkan. }\end{array}$ & & \\
\hline $\begin{array}{l}\text { Objek } \\
\text { yang } \\
\text { Dilindungi }\end{array}$ & $\begin{array}{l}\text { 1.hasil alam atau } \\
\text { kekayaan alam; } \\
\text { 2.Produsen barang hasil } \\
\text { pertanian; } \\
\text { 3. kerajinan tangan atau } \\
\text { hasil industri; }\end{array}$ & $\begin{array}{l}\text { 1. barang-barang } \\
\text { yang dihasilkan } \\
\text { oleh alam, } \\
\text { 2. barang hasil } \\
\text { pertanian, } \\
\text { 3. hasil kerajinan } \\
\text { tangan atau hasil } \\
\text { industri tertentu } \\
\text { lainnya }\end{array}$ & $\begin{array}{l}\text { 1. sumber daya alam; } \\
\text { 2.barang kerajinan } \\
\text { tangan; atau } \\
\text { 3. hasil industri; }\end{array}$ \\
\hline Pemohon & $\begin{array}{l}\text { 1.Lembaga yang } \\
\text { mewakili masyarakat } \\
\text { di daerah } \\
\text { 2. Lembaga yang diberi } \\
\text { kewenangan untuk itu; } \\
\text { 3. Kelompok konsumen } \\
\text { barang tersebut. }\end{array}$ & Idem & $\begin{array}{lr}\text { 1. Lembaga yang } \\
\text { Mewakili } \\
\text { Masyarakat } \\
\text { 2.Pemerintah Daerah } \\
\text { Provinsi atau } \\
\text { Kabupaten Kota }\end{array}$ \\
\hline
\end{tabular}

Berdasarkan tabel 2 maka tampak bahwa secara umum arah pengaturan pelindungan IG di Indonesia dapat dikatakan lebih baik dari waktu ke waktu, sehingga diharapkan memberikan kepastian hukum. Hal tersebut selaras dengan hasil riset Sudjana $^{22}$ yang mengatakan bahwa UU Merek 2016 jauh lebih memadai dalam memberikan kepastian dan perlindungan hukum pada pemegang hak atas IG. Meskipun demikian, "lebih memadai" bukan berarti kemudian tidak perlu dianalisis dan dievaluasi untuk pembangunan arah kebijakan hukum Indonesia yang lebih baik. Pelindungan IG di Indonesia pertama kali diatur dalam UU Merek 1997, bahwa UU tersebut sebagai perubahan atas UU Merek 1992 yang mana dalam ketentuan tersebut terdapat penambahan pasal khusus pada Pasal 79A-E khusus terkait IG. Adapun perubahan tersebut pada dasarnya dilatarbelakangi tahun 1994 Indonesia telah meratifikasi GATT/WTO. TRIPs sebagai paket agreements telah memberikan pengaturan secara khusus terkait dengan IG karena memang memiliki karakteristik yang berbeda dengan jenis HKI lain. Pengaturan dalam UU Merek 1997 maupun UU Merek 2001 pada dasarnya tidak terlalu beda secara signifikan, secara umum bahwa ketentuan pada UU Merek 2001 merupakan salinan dari ketentuan sebelumnya. Sementara ketentuan dalam UU Merek 2016 mengalami beberapa perubahan yang cukup signifikasi dalam hal pengaturan di bidang IG.

Dari sisi definisi ruang lingkup IG, bahwa UU Merek maupun UU Merek 2001 belum mendefinisikan secara definitif dalam ketentuan umum, namun demikian pelindungan atas suatu IG adalah suatu tanda yang menunjukkan daerah asal suatu

${ }^{22}$ Sudjana, Loc. Cit 
barang, yang karena faktor lingkungan geografis termasuk faktor alam, faktor manusia atau kombinasi dari kedua faktor tersebut, memberikan ciri dan kualitas tertentu pada barang yang dihasilkan. Apabila ketentuan tersebut dibedah maka unsur pelindungan sebuah IG terdiri atas tanda (asal barang), faktor (alam, manusia, atau kombinasi), memberikan ciri dan kualitas. Ketentuan sebagaimana tersebut berbeda sebagaimana diatur dalam UU Merek 2016 yang mana dalam UU tersebut telah memberikan definisi IG sebagai suatu tanda yang menunjukkan daerah asal suatu barang dan/atau produk yang karena faktor lingkungan geografis termasuk faktor alam, faktor manusia atau kombinasi dari kedua faktor tersebut memberikan reputasi, kualitas, dan karakteristik tertentu pada barang dan/atau produk yang dihasilkan.

Unsur-unsur bagaimana sebuah IG dapat dilindungi menjadi hal yang sangat penting, hal ini dikarenakan hal tersebut dijadikan sebagai tolok ukur utama apakah sebuah tanda dapat dilindungi melalui IG atau tidak. Utamanya bagi negara Indonesia yang pada saat itu kesadaran pentingnya pelindungan HKI (IG) relatif masih rendah, terbukti Indonesia beberapa kali menjadi Negara priority watch list karena tindakan pembajakan di bidang HKI. Terlepas dari hal tersebut bahwa sejak pengaturan IG di Indonesia diatur berdasarkan UU Merek 1997, bahwa pada tahun 2008 terdapat Indonesia memiliki IG terdaftar yakni Kopi Kintamani Bali. Artinya bahwa baru dalam kurun waktu 11 tahun Indonesia memiliki sebuah IG yang dilindungi secara nasional. Terlepas dari tingkat awareness dari masyarakat maupun dari pemerintah bahwa syarat sebagaimana ditentukan patut diperhatikan. Sebagai Negara berkembang yang baru dikenalkan dengan HKI tentu akan menjadi pertimbangan sulit atau tidaknya sebuah IG dapat dilindungi.

Formulasi dari ketiga UU Merek tersebut terletak pada unsur terakhir yakni dengan menggunakan kata "dan". Bahwa kata "dan" dapat dimaknai berarti kumulatif yang mana ketentuan tersebut harus terpenuhi semua baik itu unsur reputasi, kualitas, dan karakteristik. Meskipun bila dielaborasi lebih mendalam bahwa ketiga unsur tersebut tidak dapat ditemukan dalam pasal maupun penjelasan UU Merek tersebut. Rumusan sebagaimana dalam UU Merek dapat dimaknai sebagai ketentuan yang berlaku secara kumulatif. Berdasarkan hal tersebut, unsur tersebut dapat menyulitkan suatu IG untuk dapat dilindungi karena harus menunjukkan masing-masing unsur.

TRIPs sebagai rujukan ketentuan pelindungan IG bagi semua Negara yang telah meratifikasi GATT/WTO, pada dasarnya memberikan kelonggaran dalam hal unsur reputasi, kualitas, maupun karakteristiknya. Article 22 Ayat (1) TRIPs Agreements dinyatakan: Geographical indications are, for the purposes of this Agreement, indications which identify a good as originating in the territory of a Member, or a region or locality in that territory, where a given quality, reputation or other characteristic of the good is essentially attributable to its geographical origin. Formulasi sebagaimana tersebut bahwa secara tegas unsur-unsur yang menjadi kekhasan sebuah IG menggunakan kata "or" (dalam bahasa biasa digunakan kata "atau") artinya bahwa penggunaan kata atau bermakna alternatif, dengan kata lain 
kekhasan dari karakteristik tersebut tidak semuanya melainkan dapat memilih salah satu.

Persyaratan pemenuhan pelindungan IG yang sulit dan rumit tentu akan menjadi bahan pertimbangan bagi masyarakat atau pemerintah atau pemerhati IG di Indonesia. Belajar dari pengalaman adanya beberapa tanda yang seharusnya dapat didaftarkan dan dilindungi di Indonesia melainkan telah diambil lebih dulu oleh Negara lain, tentu merupakan sebuah kerugian. Kejadian sebagaimana hal tersebut tentu tidak perlu terjadi lagi apabila di suatu saat nanti apabila Indonesia memberikan semacam "kelonggaran" untuk dapat melindungi berbagai potensi besar IG di Indonesia. Dengan demikian, 88 IG yang telah terdaftar di Indonesia dapat bertambah lebih banyak lagi mengingat Indonesia sebagai Negara tropis memiliki berbagai keanekaragaman tanaman maupun produk yang dimiliki.

Aspek lain sebagaimana pada tabel 2 adalah terkait objek yang dilindungi di IG. Berdasarkan ketentuan dalam ketiga UU Merek telah secara definitif membatasi objek yang dapat dilindungi pada IG khusus pada barang atau produk. Ketentuan tersebut sebenarnya tidak berbeda dengan TRIPs Agreements yang menyatakan "indications which identify a good" bahwa IG yang mengidentifikasi asal suatu barang. Barang dalam konteks ini berdasarkan IG terdaftar di Indonesia adalah barang di bidang pertanian (Kopi Kintamani, Lada Putih Muntok, Tembakau Srinthil, dan beberapa produk pertanian lain), barang kerajinan tangan atau hasil industri (Mebel Ukir Jepara, Tenun Ikat Sikka, Tenun Ikat Tanibar, Kerajinan Perak Celuk, Tenun Songket).

Jasa sebagai objek yang setidaknya dapat dilindungi melalui IG merupakan potensi yang sepatutnya untuk dipertimbangkan. Hal yang memperkuat argumentasi tersebut diantaranya ada beberapa aspek, pertama bahwa ketentuan dalam Article 1, TRIPs Agreements mengenai Negara anggota. Ketentuan dalam TRIPs sebatas bersifat minimal, sehingga sangat dibolehkan untuk menambahkan objek lain termasuk IG di bidang jasa. Berdasarkan hal tersebut maka sudah sepatutnya Indonesia memanfaatkan kebebasan tersebut dengan memberikan pengaturan perihal objek pelindungan IG bidang jasa. Apa yang sudah dilakukan di beberapa Negara lain, paling tidak menjadi dasar acuan (contoh) bagaimana Negara Kanada, Meksiko, Jepang, dan Swiss mengambil peluang tersebut dengan melindungi IGnya yang tidak hanya pada bidang barang, melainkan juga jasa. Hal tersebut sangat beralasan untuk melindungi sebelum diambil oleh Negara lain ketika secara internasional IG di bidang jasa belum diakomodir melalui perjanjian di tingkat internasional.

Kedua, bahwa kekayaan yang dimiliki oleh bangsa Indonesia yang tidak hanya pada aspek sumber daya alam saja, melainkan juga sumber daya manusia. Sumber daya manusia Indonesia kaya akan potensi kekhasan di bidang jasa yang berbasis kedaerahan. Sebagai contoh Batatamba yang merupakan teknik pengobatan yang sangat terkenal di Masyarakat Banjar, Teknik untuk memaksimalkan kekuatan energi tubuh melalui Usada Bayu di Bali, Metode Penyembuhan "Dabe-Dabe" Maluku Utara untuk mengobati penyakit herpes. Beberapa contoh sebagaimana tersebut apabila tidak dilindungi secara 
proaktif bukan tidak mungkin di kemudian hari di klaim oleh pihak lain atau Negara lain yang tidak bertanggung jawab.

Ketiga, bahwa pelindungan berbagai potensi IG di bidang jasa yang saat ini dimungkinkan melalui indikasi asal. Bahwa indikasi asal dapat dimaknai sebagai ciri asal barang dan/atau jasa yang tidak secara langsung terkait dengan faktor alam. Berdasarkan hal tersebut bahwa objek perlindungan Indikasi asal tidak hanya di bidang barang, melainkan juga di bidang jasa. Pelindungan indikasi asal tanpa melalui kewajiban pendaftaran atau secara deklaratif sebagai tanda yang menunjukkan asal suatu barang dan/atau jasa yang benar dan dipakai dalam perdagangan. Meskipun dalam penjelasan UU Merek 2016 diberikan contoh kamera bermerek NIKON, Made in China. Apabila memperhatikan definisi dari indikasi asal, maka beberapa contoh di atas sangat mungkin sekali dilindungi melalui indikasi asal. Namun demikian, ketentuan indikasi asal memiliki kelemahan karena sifatnya deklaratif dan pengaturan lebih lanjut sampai dengan tulisan ini disusun masih belum ada.

Keempat, bahwa selain melalui pelindungan indikasi asal juga dimungkinkan diberikan pelindungan melalui pencatatan kekayaan intelektual komunal pada aspek pengetahuan tradisional (rezim hak cipta dan pemajuan kebudayaan). Pelindungan melalui hal tersebut relatif masih lemah dikarenakan pengetahuan tradisional pada tataran internasional juga masih belum ada kesepakatan yang disinyalir karena pengetahuan tradisional tidak banyak dimiliki oleh Negara-negara maju, melainkan ada pada Negara-negara berkembang seperti Indonesia, Brazil, dan India. Pelindungan di bidang jasa melalui IG menjadi alternatif yang sangat baik untuk dimanfaatkan oleh Indonesia seoptimal mungkin.

Berdasarkan keempat aspek tersebut, maka pelindungan IG bidang jasa menjadi salah satu alternatif untuk mengakomodir berbagai jasa yang dimiliki di Indonesia dengan kekhasan daerah yang berbeda-beda. Konsekuensi pelindungan IG di bidang jasa tentunya ada beberapa hal yang perlu penyesuaian agar kemudian dapat diimplementasikan. Hal paling pokok yang perlu disesuaikan adalah terkait dengan regulasi terkait IG yang saat ini diatur dalam UU Merek 2016. Penyesuaian tersebut meliputi definisi, objek perlindungan, pembedaan antara IG di bidang barang dan jasa, pemohon yang berhak mendaftarkan IG di bidang jasa, pemeriksaan substantif dan pembinaan dan pengawasannya.

Pelindungan IG di bidang jasa juga sangat relevan apabila dikaitkan dengan teori pelindungan hukum yang bersifat prediktif dan antisipatif. Menurut Lili Rasjidi dan I.B Wysa Putra berpendapat bahwa hukum dapat difungsikan untuk mewujudkan perlindungan yang sifatnya tidak sekedar adaptif dan fleksibel, melainkan juga prediktif dan antisipatif. ${ }^{23}$ Hukum bertujuan memprediksi hal-hal yang dapat terjadi kedepan, sehingga dapat hal tersebut dapat di antisipasi oleh hukum. Berkaitan dengan pelindungan IG di bidang jasa yang saat ini belum diatur dalam UU Merek dan IG

\footnotetext{
${ }^{23}$ Lili Rasjidi dan I.B Wysa Putra, Hukum Sebagai Suatu Sistem, Bandung: Remaja Rusdakarya, 1993, hlm. 118.
} 
sangat penting untuk memprediksi sekaligus mengantisipasi tindakan pihak ketiga atas berbagai potensi IG di bidang jasa yang dimiliki oleh Indonesia.

Teori lain yang juga relevan dengan penting pelindungan IG di bidang jasa adalah teori integratif dan koordinatif. Menurut Fitzgerald, hukum bertujuan mengintegrasikan \& mengkoordinasikan berbagai kepentingan dalam masyarakat. ${ }^{24}$ Dalam konteks pelindungan IG dalam penelitian ini, bagaimana kemudian pelindungan IG tidak hanya di bidang barang saja, melainkan juga sangat penting dan patut untuk juga diberi pelindungan secara integratif yakni juga meliputi di bidang jasa. IG sebagai HKI yang mana kepemilikannya secara komunal maka kepentingan masyarakat yang lebih luas sangat perlu untuk diprioritaskan untuk dapat diberikan pelindungan hukum.

Teori hak milik yang juga menjadi landasan penting untuk memperkuat pelindungan IG di bidang jasa adalah teori kepemilikan sosial. Teori kepemilikan sosial merupakan counter hegemoni atas teori kapitalis yang mendasarkan kepada kepemilikan bersama. ${ }^{25}$ Filosofi ini dibangun oleh Karl Marx yang mengutamakan kepentingan sosial sebagai suatu hal yang paling utama. Bahwa IG sebagai kekayaan intelektual yang dimiliki oleh masyarakat umum bersifat komunal (sosial), ${ }^{26}$ maka pelindungan IG di bidang jasa sangat relevan dengan teori kepemilikan bersama karena rawan diakui, dicuri dan dibajak oleh negara lain apabila Indonesia masih belum memberikan pelindungan melalui peraturan hukum.

\section{PENUTUP}

Berdasarkan analisis di atas maka dapat disimpulkan bahwa peluang pelindungan di bidang jasa (sebuah diagnosa awal) sangat terbuka dengan argumentasi yang terdiri atas 4 aspek antara lain ketentuan TRIPS agreement yang bersifat terbuka, potensi kekhasan di bidang jasa yang berbasis kedaerahan, pelindungan melalui indikasi asal yang relatif masih memiliki kelemahan, dan pelindungan melalui kekayaan intelektual komunal (pengetahuan tradisional) yang juga relatif masih memiliki kelemahan. Peluang pelindungan juga sangat relevan dengan beberapa teori pelindungan hukum antara lain: teori pelindungan hukum yang bersifat prediktif dan antisipatif, teori integratif dan koordinatif, dan juga teori kepemilikan sosial.

\footnotetext{
${ }^{24}$ Satijipto Raharjo, Ilmu Hukum, Bandung: PT. Citra Aditya Bakti, 2000, hlm. 53 dalam Dara Quthni Effida, "Tinjauan Yuridis Indikasi Geografis sebagai Hak Kekayaan Intelektual Non-Individual (Komunal)", Jurnal Ius Civile, Vol 3 No 2, 2019, hlm. 59.

${ }^{25}$ Dara Quthni Effida, "Tinjauan Yuridis Indikasi Geografis sebagai Hak Kekayaan Intelektual NonIndividual (Komunal)", Jurnal Ius Civile, Vol 3 No 2, 2019, hlm. 63.

${ }^{26}$ Robiatul Adawiyaha dan Rumawia, "Pengaturan Hak Kekayaan Intelektual dalam Masyarakat Komunal di Indonesia”, Jurnal Ilmiah Hukum Kenotariatan, Vol.10 No.1, 2021, hlm. 1.
} 
Dialogia luridica: Jurnal Hukum Bisnis dan Investasi

Volume 13 Nomor 1, November 2021

\section{DAFTAR PUSTAKA}

\section{Buku}

Cita Yustisia Serfiyani, et.al, Buku Pintar HAKI dan Warisan Budaya, Yogyakarta: Gadjah Mada University Press, 2017.

Miranda Risang Ayu, Memperbincangkan Hak Kekayaan Intelektual Indikasi Geografis, Bandung: Alumni, 2006.

Rahmi Jened, Hak Kekayaan Intelektual Penyalahgunaan Hak Eksklusif, Surabaya: Airlangga University Press, 2010.

Saky Septiono, Perlindungan Indikasi Geografis dan Potensi Indikasi Geografis Indonesia, Jakarta: DJKI Kementerian Hukum dan HAM RI, 2009.

Yusran Isnaini, Buku Pintar HAKI Tanya Jawab Seputar Hak Kekayaan Intelektual, Bogor: Ghalia, 2010.

\section{Jurnal}

Amiek Soemarmi, et.al, “Amalia Diamantina, Konsep Negara Kepulauan dalam Upaya Perlindungan Wilayah Pengelolaan Perikanan Indonesia”, Masalah-Masalah Hukum, Vol. 48 No. 3, 2019.

Ayub Torri Satriyo Kusumo, "Optimalisasi Pengelolaan dan Pemberdayaan Pulau-Pulau Terluar dalam Rangka Mempertahankan Keutuhan Negara Kesatuan Republik Indonesia”, Jurnal Dinamika Hukum, Vol. 10 No 3, 2010.

Dara Quthni Effida, "Tinjauan Yuridis Indikasi Geografis sebagai Hak Kekayaan Intelektual Non-Individual (Komunal)", Jurnal Ius Civile, Vol 3 No 2, 2019.

Fokky Fuad dan Avvan Andi Latjeme, "Perlindungan Indikasi Geografis Aset Nasional pada Kasus Kopi Toraja”, Jurnal Magister Ilmu Hukum (Hukum dan Kesejahteraan), Vol. 2 No. 2, 2017

I Ketut Haris Wiranata dan Anak Agung Sri Indrawati, "Pendaftaran Kembali Hak Merek Dagang Indikasi Geografis”, Jurnal Kertha Semaya, Vol. 2 No. 5, 2014.

Isnani, "Identifikasi dan Pemanfaatan Indikasi Geografis dan Indkasi Asal melalui Program Pembinaan Pada Masyarakat", Jurnal Pengabdian Hukum Indonesia, Vol. 2 No. 1, 2019.

Isni Wahyuningsih, "Meninjau Kembali Tujuan Pendirian dan Fungsi Museum-museum di Kompleks Taman Wisata Candi Borobudur", Jurnal Konservasi Cagar Budaya Borobudur, Vol. 10 Nomor 2, 2016.

Lily Karuna Dewi dan Putu Tuni Cakabawa Landra, "Perlindungan Produk-Produk Berpotensi Hak Kekayaan Intelektual Melalui Indikasi Geografis", Jurnal Kertha Semaya, Vol 7 No 3, 2019.

Muhammad Ali Ridla, "Perlindungan Indikasi Geografis Terhadap Kopi Yang Belum Terdaftar Menurut First-To-Use-System", Jurnal Hukum Bisnis Bonum Commune, Vol. 2 No 2, 2019.

Ni Wayan Rainy Priadarsini Sukiada dan Anak Agung Ayu Intan Parameswari, "Nation Branding Kopi Arabika Kintamani”, SOCA: Jurnal Sosial Ekonomi Pertanian, Vol. 14 No. 1, 2020. 
Nizar Apriansyah, "Protection of Geographical Indications within the Scope of Improvement of Regional Economy", Jurnal Penelitian Hukum De Jure, Vol. 18 No. 4, 2018.

Robiatul Adawiyaha dan Rumawia, "Pengaturan Hak Kekayaan Intelektual dalam Masyarakat Komunal di Indonesia”, Jurnal Ilmiah Hukum Kenotariatan, Vol.10 No.1, 2021.

Sudjana, "Implikasi Perlindungan Indikasi Geografis Berdasarkan Undang-Undang Nomor 20 Tahun 2016 Terhadap Pengembangan Ekonomi Lokal”, Jurnal Veritas Et Justitia, Vol. 4 No. 1, 2018.

Trias Palupi Kurnianingrum, "Pelindungan Hak Ekonomi Atas Indikasi Geografis", Jurnal Negara Hukum, Vol. 7 No. 1, 2016.

Wahyu Sasongko, "Indikasi Geografis Rezim HKI yang Bersifat Sui Generis", Jurnal Media Hukum, Vol. 19 No 1, 2012.

\section{Peraturan Perundang-undangan}

Undang-Undang Nomor 14 Tahun 1997 tentang tentang Perubahan Atas UndangUndang Nomor 19 Tahun 1992 tentang Merek

Undang-Undang Nomor 15 Tahun 2001 tentang Merek

Undang-Undang Nomor 20 Tahun 2016 tentang Merek dan Indikasi Geografis.

\section{Pranalar Luar}

E Indikasi Geografis, http://ig.dgip.go.id/, diakses pada pada tanggal 25 November pukul 20.00 WIB.

Pusat Data Nasional Kekayaan Intelektual Komunal Indonesia, http://kikomunalindonesia.dgip.go.id/index.php/, diakses pada pada tanggal 30 November pukul 19.30 WIB. 